\title{
Pengaruh Corporate Social Responsibility (CSR) dan Karakteristik Perusahaan terhadap Praktik Penghindaran Pajak Perusahaan yang Terdaftar di Bursa Efek Indonesia
}

\author{
Androni Susanto ${ }^{1}$ Veronica $^{2 *}$ \\ ${ }^{1,2)}$ Universitas Internasional Batam \\ androni@uib.ac.id, 1842021.veronica@uib.ac.id
}

*Corresponding Author

Diajukan : 18 Nopember 2021

Disetujui $\quad: 28$ Nopember 2021

Dipublikasi : 2 Januari 2022

\begin{abstract}
This study aims to analyze the effect of Corporate Social Responsibility (CSR) and company characteristics on corporate tax avoidance. The sampling technique used was purposive sampling. The sample of this research is the financial statements and sustainability reports of 73 companies listed on the Indonesia Stock Exchange (IDX) for the 2016-2020 period. The analytical method used is multiple linear regression. The results of this study indicate that CSR has a significant positive effect on current taxes, which means that companies that are responsible to stakeholders tend to avoid tax avoidance practices or pay more taxes. CSR, ROA and firm size have a significant negative effect on tax avoidance. Leverage and intangible assets have a significant positive effect on tax avoidance. Other company characteristics variables such as fixed assets, operating cash flow, sales growth have no significant effect on tax avoidance.
\end{abstract}

Keywords: CSR; firm characteristic; Indonesia; Stakeholder; Tax Avoidance

\section{PENDAHULUAN}

Saat ini, perusahaan tidak hanya dituntut untuk berperan aktif di sektor perekonomian tetapi juga di sektor lingkungan dan sektor sosial. Perusahaan yang aktif melaksanakan ketiga peranan tersebut dapat disebut telah melaksanakan CSR. Perusahaan yang aktif melaksanakan CSR, tentu telah melaksanakan tanggung jawabnya kepada pemegang saham, pemerintah, karyawan, konsumen, pemasok, dan masyarakat. Namun, tujuan utama didirikan perusahaan tidak lepas untuk memakmurkan pemegang saham.

Berdasarkan teori keagenan, hubungan timbal balik antara pemegang saham dan manajer tidak lepas dari konflik kepentingan. Pemegang saham ingin pengembalian yang besar dan cepat atas investasinya, sedangkan manajer ingin imbalan sebesar-besarnya atas kinerjanya. Manajer selaku pelaksana kegiatan akan mengetahui informasi perusahaan lebih banyak daripada pemegang saham. Keadaan ini memberi kesempatan kepada manajer untuk melakukan tindakan oportunistik seperti penghindaran pajak untuk memaksimalkan laba perusahaan agar manajer mendapatkan imbalan yang besar atas kinerjanya (Anthony et al., 2011).

Menurut Friedman (1970) kewajiban perusahaan hanyalah memaksimalkan kekayaan para pemegang saham, yang menyarankan perusahaan harus terlibat dengan aktivitas seperti penghindaran pajak. Selain itu, penghindaran pajak tidaklah melanggar aturan karena memanfaatkan celah dari ketentuan perpajakan suatu negara (Lathifa, 2019). Namun, penghindaran pajak tidaklah bebas dari biaya. Biaya yang dimaksud adalah biaya implementasi dan kehilangan reputasi. Praktik penghindaran pajak yang agresif dianggap kurang etis oleh masyarakat, sehingga dapat menyebabkan sanksi negatif seperti hilangnya reputasi perusahaan atau eksekutif, pengingkatan tekanan politik dan media, potensi denda, bahkan boikot dari konsumen (Hanlon \& Slemrod, 2009). Efek negatif dari penghindaran pajak tersebut dapat 
dikurangi dengan melaksanakan CSR.

CSR dapat mengurangi efek negatif penghindaran pajak karena CSR memiliki kaitan dengan teori pemangku kepentingan dan teori legitimasi. Teori pemangku kepentingan menyatakan bahwa perusahaan yang bertanggungjawab harus mempertimbangkan kepentingan semua pihak yang terdampak dari tindakan mereka. Teori legitimasi menyatakan bahwa perbedaan perusahaan dan nilai-nilai sosial dapat mengancam legitimasi yang menyebabkan berakhirnya eksistensi perusahaan. Agar perusahaan dapat terus eksis dalam masyarakat maka perusahaan membutuhkan dukungan para pemangku kepentingan, sehingga perusahaan harus mengikuti nilai-nilai yang dipegang oleh masyarakat (Jessica \& Toly, 2014).

Dalam UU No. 36 Tahun 2008, beberapa kegiatan CSR dapat mengurangi pajak penghasilan badan, sehingga dengan adanya biaya CSR, perusahaan dapat mengurangi laba fiskal dan mengurangi pajak yang terutang. Hal ini menjadi dasar bahwa kegiatan CSR mempengaruhi perilaku penghindaran pajak perusahaan. Perusahaan dapat memanfaatkan CSR dalam strategi penghindaran pajak. CSR bertindak sebagai pengurang pajak dan tameng dari efek negatif praktik penghindaran pajak yang agresif.

Perusahaan yang mempunyai kinerja CSR yang baik seharusnya dapat menghindari praktik penghindaran pajak karena bentuk keikutsertaan perusahaan dalam masyarakat adalah dengan membayar pajak (Hoi et al., 2013). Sehingga, perusahaan yang mempunyai CSR yang baik kemungkinan kecil melakukan penghindaran pajak. Namun ironisnya, terdapat perusahaan yang memiliki kinerja CSR yang baik cenderung melakukan praktik penghindaran pajak.

Pada tahun 2018, rasio penerimaan perpajakan (tax ratio) Indonesia hanya mencapai 11,5\%. Angka tersebut merupakan angka terendah dibandingkan dengan 21 negara di Asia-Pasifik dan masih di bawah standar negara-negara Association of Southeast Asian Nation (ASEAN) (Wildan, 2020). World Bank menyebutkan bahwa rata-rata tax ratio dunia adalah sebesar 15,06\%. Dapat disimpulkan bahwa tax ratio Indonesia tergolong rendah (Kemenkeu, 2019). Organisation on Economic Cooperation and Development (OECD) mengungkapkan salah satu penyebab rendahnya rasio penerimaan pajak Indonesia adalah penghindaran pajak (RSAPE, 2020).

Riset Centre for Governance, Institutions, and Organizations National University of Singapore (NUS) Business School menunjukkan kualitas implementasi CSR di Indonesia tergolong rendah (Suastha, 2016). Berdasarkan informasi dipaparkan dapat terlihat adanya korelasi positif antara CSR dan penghindaran pajak. CSR yang rendah cenderung melakukan penghindaran pajak.

Zeng (2019) menemukan hubungan signifikan positif antara CSR dan penghindaran pajak, sedangkan, Kim \& Im (2017) menemukan CSR berhubungan signifikan negatif dengan penghindaran pajak. Sampai saat ini, topik hubungan CSR dan penghindaran pajak masih diperdebatkan dan belum disimpulkan (Renselaar, 2016). Sehingga penelitian ini perlu dilaksanakan untuk memverifikasi penelitian-penelitian yang sudah ada dan memberikan bukti apakah CSR yang rendah mengindikasikan penghindaran pajak yang agresif.

Penelitian ini juga menganalisis pengaruh variabel karakteristik perusahaan seperti profitabilitas, ukuran perusahan, arus kas operasi, aset tetap, aset tak berwujud, dan pertumbuhan penjualan terhadap penghindaran pajak. Berdasarkan penelitian yang dikumpulkan, karakteristik perusahaan memiliki pengaruh yang signifikan terhadap praktik penghindaran pajak. Penelitian ini diharapkan dapat menjadi bahan pertimbangan dan berkontribusi kepada seluruh pihak terutama pihak regulator seperti Direktorat Jenderal Pajak (DJP) dan pemerintah dalam menentukan kebijakan yang tepat untuk mengatasi masalah perpajakan di Indonesia.

\section{Penelitian Terdahulu}

\section{STUDI LITERATUR}

Sejak awal 2010-an, sekelompok peneliti mulai membuat hipotesis bahwa CSR mempengaruhi keputusan untuk melakukan penghindaran pajak (Mao \& Wu, 2019). Abdelfattah \& Aboud (2020) menyatakan bahwa perusahaan yang melakukan penghindaran pajak cenderung meningkatkan pengungkapan CSR. Hal ini dilakukan untuk mengembangkan persepsi positif kode etik perusahaan dan meningkatkan reputasi publik serta media. Perusahaan yang berfokus pada CSR seharusnya meminimalkan tindakan oportunistik seperti penghindaran pajak karena 
penghindaran pajak tidak sejalan dengan etika dan norma yang berlaku di masyarakat (Pratiwi \& Siregar, 2019).

Penelitian tentang hubungan CSR dengan penghindaran pajak telah banyak diteliti oleh peneliti-peneliti sebelumnya. Davis et al. (2016) menginvestigasi hubungan antara pembayaran pajak perusahaan dan tanggung jawab sosial perusahaan. Penelitian ini mengambil sampel semua perusahaan terbuka di Amerika Serikat. Davis et al. (2016) menemukan bahwa perusahaan dengan CSR bertanggung jawab yang tinggi cenderung melakukan penghindaran pajak atau membayar pajak lebih rendah. Davis et al. (2016) menemukan hubungan signifikan negatif antara CSR dan cash Effective Tax Rate (ETR) dan menemukan hubungan signifikan positif antara CSR dan tax-lobbying. Jadi, penelitian ini memberikan bukti bahwa perusahaan yang bertanggung jawab tidak memandang CSR dan pajak saling melengkapi (komplemen).

Park (2017) meneliti hubungan antara CSR dan penghindaran pajak dengan proksi pengukuran book-tax differences (BTD) pada perusahaan-perusahaan di Korea Selatan. Park (2017) menemukan bahwa layanan sosial, kepuasan karyawan, dan kontribusi kepada perkembangan ekonomi berpengaruh signifikan negatif terhadap praktik penghindaran pajak. Kehati-hatian finansial, keadilan dan transparansi, serta perlindungan konsumen tidak berpengaruh secara signifikan terhadap praktik penghindaran pajak. Hanya perlindungan lingkungan yang berhubungan positif secara signifikan terhadap praktik penghindaran pajak. Secara keseluruhan, penelitian Park mengkonfirmasi bahwa perusahaan dengan kinerja CSR yang tinggi kemungkinan kecil melakukan praktik penghindaran pajak yang agresif.

Lanis \& Richardson (2018) meneliti dampak direktur luar terhadap hubungan antara kinerja CSR dan agresivitas pajak. Penelitian ini menemukan adanya hubungan negatif antara kinerja CSR dan agresivitas pajak. Peneliti juga menemukan bahwa direktur luar dalam dewan semakin memperkuat hubungan negatif antara CSR dan agresivitas pajak.

Gulzar et al. (2018) melakukan penelitian tentang pengaruh CSR terhadap penghindaran pajak pada perusahaan-perusahaan di China periode 2009-2015. Peneliti menemukan bahwa CSR berhubungan negatif dengan current ETR dan cash ETR yang mewakili penghindaran pajak. Jadi penelitian ini menemukan bahwa perusahaan yang memiliki tanggung jawab sosial yang tinggi kemungkinan besar melakukan penghindaran pajak.

Penelitian López-González et al. (2019) meneliti hubungan CSR terhadap penghindaran pajak dan bagaimana kepemilikan keluarga mempengaruhi strategi penghematan pajak dengan CSR. Hasil penelitian mendukung bahwa perusahaan yang aktif dalam kegiatan CSR cenderung mengurangi praktik penghindaran pajak. Namun, peneliti menemukan bahwa kepemilikan keluarga berpengaruh positif terhadap praktik penghindaran pajak.

Penelitian Ortas \& Gallego-Álvarez (2020) membahas efek moderasi budaya nasional di antara hubungan CSR dan agresivitas pajak pada 2.696 perusahaan yang tersebar di 30 negara. Peneliti membagi variabel kinerja CSR menjadi 3 variabel, yaitu kinerja lingkungan, kinerja sosial, dan kinerja tata kelola. Ortas \& Gallego-Álvarez (2020) menemukan ketiga variabel CSR tersebut berhubungan signifikan negatif terhadap agresivitas pajak. Sehingga penelitian ini mendukung bahwa perusahaan yang memiliki kinerja lingkungan, kinerja sosial, dan kinerja tata kelola yang tinggi kemungkinan kecil melakukan praktik agresivitas pajak.

\section{ROA}

Profitabilitas perusahaan dapat diukur dengan ROA. Semakin tinggi ROA, semakin besar kemungkinan perusahaan terlibat dalam agresivitas perpajakan (Ortas \& Gallego-Álvarez, 2020). Besarnya ROA akan berpengaruh pada nilai ETR. ETR adalah ukuran praktik penghindaran pajak. Semakin tinggi ROA, maka nilai ETR akan semakin rendah karena meningkatnya praktik penghindaran pajak. Perusahaan yang memiliki profitabilitas yang tinggi memiliki peluang untuk melakukan perencanaan pajak (tax planning) yang matang untuk meminimalkan pembayaran pajak (Susanti, 2018).

Mohanadas et al. (2019) meneliti hubungan antara ROA dan penghindaran pajak pada perusahaan di Malaysia. Peneliti menggunakan proksi current ETR untuk mengukur penghindaran pajak. Penelitian ini menemukan bahwa ROA berpengaruh signifikan negatif terhadap current ETR. Hal ini berarti perusahaan dengan profitabilitas yang tinggi cenderung 
memiliki beban pajak kini yang lebih rendah. Pajak kini yang rendah mengindikasikan perusahaan terlibat dalam praktik penghindaran pajak.

\section{Ukuran Perusahaan}

Richardson \& Lanis (2007) menyatakan bahwa semakin besar ukuran perusahaan maka semakin besar kemungkinan perusahaan melakukan agresivitas pajak. Perusahaan besar memiliki lebih banyak keuntungan dan kekuatan politik, sehingga perusahaan besar lebih mampu mengurangi beban pajak dibandingkan perusahaan kecil (Jessica \& Toly, 2014). Berikut beberapa hasil penelitian antara ukuran perusahaan dan penghindaran pajak.

Penelitian Kiesewetter \& Manthey (2017) menemukan hubungan signifikan positif antara ukuran perusahaan dan ETR pada perusahaan Eropa dalam sistem ekonomi liberal. Hasil ini berarti semakin besar ukuran perusahaan maka semakin besar beban pajak perusahaan. Beban pajak yang besar mengindikasikan perusahaan tidak terlibat dalam praktik penghindaran pajak. Namun peneliti tidak menemukan hubungan yang signifikan antara ukuran perusahaan dan ETR pada perusahaan dalam sistem ekonomi komando.

Penelitian hubungan ukuran perusahaan dan penghindaran pajak pada perusahaan di Eropa juga dilakukan oleh Fourati et al. (2019). Peneliti menemukan bahwa ukuran perusahaan berpengaruh signifikan negatif terhadap ETR dan BTD. Hasil penelitian ini berbanding terbalik dengan hasil penelitian Kiesewetter \& Manthey (2017) dengan proksi yang sama yaitu ETR.

\section{Leverage}

Perusahaan dengan leverage yang tinggi kemungkinan besar melakukan penghindaran pajak. Hal ini dapat dilakukan dengan memanfaatkan pembayaran bunga dalam strategi pengurangan pajak perusahaan (Lanis \& Richardson, 2012). Pengaruh leverage terhadap penghindaran pajak telah dilakukan oleh banyak peneliti.

Wiratmoko (2018) tidak menemukan hubungan yang signifikan antara leverage dan cash ETR pada perusahaan di Indonesia. Sedangkan pada perusahaan di Malaysia, peneliti menemukan hubungan signifikan negatif antara leverage dan cash ETR. Hal ini berarti semakin besar rasio utang maka semakin kecil pembayaran kas pajak perusahaan. Pembayaran kas pajak yang kecil mengindikasikan penghindaran pajak.

Penelitian antara leverage dan penghindaran pajak pada perusahaan di Malaysia juga diteliti oleh Mohanadas et al. (2019). Peneliti menemukan hubungan signifikan negatif antara leverage dan current ETR. Hal berarti semakin besar nilai leverage maka semakin kecil beban pajak kini perusahaan. Beban pajak kini yang rendah mengindikasikan praktik penghindaran pajak. Hasil penelitian ini mendukung hasil penelitian Wiratmoko (2018).

\section{Arus Kas Operasi}

Arus kas operasi merupakan indikator penentu apakah pendapatan dari operasi entitas dapat melunasi utang, menjalankan kegiatan operasional, membayar pajak, dan dividen serta melakukan investasi baru tanpa bergantung pada dana eksternal. Semakin besar nilai arus kas operasi maka semakin besar laba yang diterima perusahaan. Laba yang besar mendorong perusahaan untuk melakukan penghindaran pajak (Gazali et al., 2020).

Penelitian hubungan arus kas operasi terhadap penghindaran pajak pada perusahaan di China juga diteliti oleh Liu \& Lee (2019). Peneliti menggunakan pengukuran BTD oleh Desai \& Dharmapala (2006). Pada tabel ke-sembilan, peneliti menemukan hubungan signifikan positif antara arus kas operasi dan penghindaran pajak.

\section{Aset Tetap}

Aset tetap menggambarkan banyaknya investasi entitas terhadap aset tetapnya. Aset tetap yang dimiliki akan menimbulkan beban penyusutan. Beban penyusutan tersebut dapat dimanfaatkan oleh manajemen untuk mengurangi penghasilan kena pajak. Hal tersebut tertuang dalam UU No. 36 Tahun 2008 tentang pajak penghasilan (Ramadhania, 2020).

Ortas \& Gallego-Álvarez (2020) menganalisis pengaruh aset tetap terhadap penghindaran pajak pada perusahaan di 30 negara periode 2002-2014. Rumus pengukuran penghindaran pajak yang 
digunakan peneliti adalah rumus ETR-STR oleh Hanlon \& Heitzman (2010) dan dua rumus pengukuran ETR oleh G. A. Richardson \& Lanis (2012) yang telah dikalikan negatif satu. Peneliti menemukan bahwa aset tetap berpengaruh signifikan positif terhadap penghindaran pajak.

\section{Aset Tak Berwujud}

Aset tak berwujud umumnya memiliki nilai yang tidak pasti sehingga aset tak berwujud sulit untuk diukur nilai wajarnya. Hal ini banyak dimanfaatkan perusahaan untuk mentransfer kekayaan kepada perusahaan berafiliasi di negara dengan tarif pajak yang lebih rendah (tax haven). Manajemen perusahaan akan membayar royalti atas penggunaan aset tak berwujud dengan nilai tinggi kepada perusahaan berafiliasi di negara dengan tarif pajak yang rendah. Beban perusahaan akan bertambah dan mengakibatkan penghasilan yang dikenakan pajak menurun atau bahkan tidak dikenakan pajak (Novira et al., 2020). Sehingga semakin tinggi nilai aset tak berwujud perusahaan maka semakin besar kemungkinan perusahaan melakukan praktik penghindaran pajak.

Zeng (2019) menguji hubungan antara aset tak berwujud dan penghindaran pajak pada perusahaan di 35 negara periode 2011-2015. Peneliti menggunakan ETR-STR, BTD, residual BTD sebagai proksi pengukuran penghindaran pajak. Penelitian ini menemukan bahwa aset tak berwujud berpengaruh signifikan positif terhadap ETR-STR dan aset tak berwujud tidak berpengaruh signifikan terhadap BTD dan residual BTD. Penelitian ini mendukung bahwa semakin besar nilai aset tak berwujud maka semakin besar kemungkinan perusahaan melakukan penghindaran pajak.

\section{Pertumbuhan Penjualan}

Peningkatan pertumbuhan penjualan dapat mencerminkan profitabilitas dan kinerja baik perusahaan. Peningkatan pertumbuhan penjualan cenderung membuat perusahaan mendapatkan keuntungan yang besar, sehingga kemungkinan perusahaan melakukan praktik penghindaran pajak semakin besar pula (Susanti, 2018). Penelitian hubungan antara pertumbuhan penjualan dan penghindaran pajak menghasilkan hasil yang beragam.

Kim \& Im (2017) meneliti pengaruh pertumbuhan penjualan terhadap penghindaran pajak pada perusahaan di Korea Selatan. Peneliti menggunakan BTD sebagai proksi pengukuran penghindaran pajak. Peneliti menemukan hubungan signifikan negatif antara pertumbuhan penjualan dan BTD atau penghindaran pajak. Hal ini berarti semakin besar pertumbuhan penjualan maka semakin kecil selisih antara laba komersial dan laba fiskal. Selisih yang kecil antara laba komersial dan laba fiskal berarti kemungkinan perusahaan melakukan penghindaran pajak semakin kecil pula.

\section{METODE}

Peneliti menggunakan laporan keuangan dan laporan keberlanjutan perusahaan yang terdaftar di BEI sebagai objek penelitian ini. Data diperoleh dari website BEI yaitu http://www.idx.co.id/ dan website perusahaan terbuka yang bersangkutan. Rentang waktu yang diambil sebagai sampel diantara tahun 2016-2020. Dalam mengambil sampel, peneliti menggunakan teknik purposive sampling. Kriteria peneliti dalam pemilihan sampel diantaranya laporan keuangan audit perusahaan yang terdaftar di BEI periode 2016-2020 tersedia selama 5 tahun berturut-turut, perusahaan menerbitkan laporan keberlanjutan berstandar GRI dalam periode 2016-2020, dan laporan keuangan dan laporan keberlanjutan terdapat informasi yang diperlukan.

Penelitian ini bertujuan untuk menganalisis hubungan antara variabel independen terhadap variabel dependen. Perangkat lunak yang digunakan dalam penelitian ini adalah EView 10. Tahap-tahap analisis data meliputi uji outlier, analisis statistik deskriptif, uji Pooled Least Square (PLS), uji Fixed Effect Model (FEM), uji chow, uji Random Effect Model (REM), uji hausman dan uji lagrange multiplier.

\section{Definisi Operasional Variabel dan Pengukuran Variabel Dependen}

Penghindaran pajak adalah suatu strategi meminimalkan beban pajak dengan memanfaat celah 
dari ketentuan perpajakan suatu negara. Proksi pengukuran penghindaran pajak dalam penelitian ini adalah current ETR menurut Gulzar et al. (2018). Current ETR dipilih sebagai proksi pengukuran penghindaran pajak karena rata-rata pembayaran pajak perusahaan di Indonesia masih bersifat akrual. Current ETR dirumuskan:

$$
\text { Current ETR }_{i, t}=\frac{\text { (Total Beban Pajak }- \text { Beban Pajak Tangguhan) }}{\text { Laba Sebelum Pajak } k_{i, t}}
$$

Sumber: Gulzar et al. (2018)

Current ETR adalah pengukuran kebalikan dari penghindaran pajak. ETR yang kecil mengindikasikan keterlibatan penghindaran pajak yang tinggi dan kebalikan. Current ETR didasarkan pada perhitungan pajak kini perusahaan.

\section{Variabel Independen}

\section{Corporate Social Responsibility (CSR)}

CSR adalah tanggung jawab perusahaan atas dampak keputusan dan aktivitas terhadap masyarakat dan lingkungan hidup secara transparan, beretika, dan berkontribusi kepada pembangunan berkelanjutan (ISO 26000, 2017). CSR diproksikan dalam pengungkapan CSR perusahaan. Nazari et al. (2017) mengungkapkan adanya hubungan positif antara praktik CSR dan pengungkapan CSR.

Berdasarkan Global Sustainability Standards Board (2016) terdapat 17 indikator topik ekonomi, 32 indikator topik lingkungan, dan 40 indikator topik sosial. Dalam pengukuran CSR, penulis menggunakan rumus peneliti sebelumnya yaitu Wiratmoko (2018) dengan mengubah jumlah item dari 91 item menjadi 89 item sesuai dengan jumlah item pengungkapan dalam pedoman GRI 2016. Rumus untuk mengukur pengungkapan CSR yaitu:

$C S R I_{j}:$ Indeks pengungkapan CSRj

$$
\mathrm{CSRI}_{\mathrm{j}}=\frac{\sum \mathrm{Xij}}{\mathrm{Nj}}
$$

$\sum X i j$ : Nilai 1 jika item i diungkapkan; 0 jika item i tidak diungkapkan

$N j$ : Jumlah item perusahaan $\mathrm{i}, \mathrm{ni} \leq 89$.

\section{ROA}

ROA adalah rasio profitabilitas yang mengukur kemampuan perusahaan menghasilkan keuntungan dari penggunaan aset yang dimilikinya. Rasio dinyatakan dalam persentase. Semakin tinggi persentase ROA, semakin baik kinerja perusahaan dalam menghasilkan keuntungan bersih.

$$
\begin{gathered}
\text { ROA }=\frac{\text { Laba setelah pajak }}{\text { Total Aset }} \\
\text { Sumber: Gulzar } \text { et al. }(2018)
\end{gathered}
$$

\section{Ukuran Perusahaan}

Ukuran perusahan merupakan besarnya aset yang dimiliki perusahaan. Besarnya aset dapat menentukan besar kecil atau ukuran perusahaan (Susanti, 2018).

\section{Ukuran Perusahaan $=$ Ln Total Aset \\ Sumber: Gulzar et al. (2018)}

\section{Leverage}

Leverage adalah rasio solvabilitas untuk menilai seberapa besar perusahaan mengandalkan dana yang memiliki beban bunga untuk membiayai asetnya. Semakin tinggi rasio, semakin besar pula risiko terkait dengan operasional perusahaan. Leverage yang rendah menunjukkan perusahaan cenderung konservatif dalam meminjam dana untuk menghindari risiko yang ditimbulkan. Leverage yang rendah berarti hanya sebagian kecil aset perusahaan yang dibiayai dengan hutang.

\section{Arus kas operasi}

$$
\begin{gathered}
\text { Leverage }=\frac{\text { Total Kewajiban }}{\text { Total Aset }} \\
\text { Sumber: Gulzar } \text { et al } \text { (2018) }
\end{gathered}
$$

Arus kas operasi adalah arus kas yang berasal dari transaksi terkait operasional perusahaan pada periode tertentu. 


\section{Aset Tetap}

Sumber: Gulzar et al. (2018)

Aset tetap adalah aktiva berwujud yang digunakan dalam kegiatan operasional perusahaan untuk memproduksi, menyediakan barang dan jasa, serta direntalkan untuk menghasilkan penghasilan.

\section{Aset Tak berwujud}

$$
\begin{gathered}
\text { Aset Tetap }=\frac{\text { Aset Tetap Neto }}{\text { Total Aset }} \\
\text { Sumber: Gulzar } \text { et al. } \text { (2018) }
\end{gathered}
$$

Aset tak berwujud adalah aktiva non-moneter yang diindentifikasikan tanpa wujud fisik serta digunakan untuk tujuan administratif perusahaan, disewakan kepada pihak lain, menghasilkan dan mengirimkan barang atau jasa.

\section{Pertumbuhan Penjualan}

$$
\begin{gathered}
\text { Aset Tak Berwujud }=\frac{\text { Aset Tak Berwujud }}{\text { Total Aset }} \\
\text { Sumber: Gulzar et al. }(2018)
\end{gathered}
$$

Pertumbuhan penjualan adalah perubahan total penjualan pada laporan tahunan perusahaan yang dapat menggambarkan peluang perusahaan dan keuntungan di masa yang akan datang (Susanti, 2018).

$$
\text { Pertumbuhan Penjualan }=\frac{\text { Penjualan Sekarang }- \text { Penjualan Periode Sebelumnya }}{\text { Penjualan Periode Sebelumnya }}
$$

HASIL

Tabel 1. Hasil Uji Statistika Deskriptif Kuantitatif

\begin{tabular}{llrrrr}
\hline \multirow{2}{*}{ Keterangan } & \multicolumn{5}{c}{ Statistik Deskriptif } \\
\cline { 2 - 6 } & $\mathbf{N}$ & Minimum & Maksimum & Mean & $\begin{array}{c}\text { Std. } \\
\text { Deviasi }\end{array}$ \\
\hline Current ETR & 310 & $-0,782452$ & 1,018855 & 0,209420 & 0,213967 \\
CSR & 310 & 0,000000 & 0,685393 & 0,221856 & 0,162401 \\
ROA & 310 & $-0,229531$ & 0,242632 & 0,034942 & 0.060578 \\
Ukuran Perusahaan & 310 & 27,50692 & 34,81508 & 30,99765 & 1,512313 \\
Leverage & 310 & 0,076894 & 1,180077 & 0,549323 & 0,241933 \\
Arus Kas Operasi & 310 & $-3.20 \mathrm{E}+13$ & $4.15 \mathrm{E}+13$ & $3.23 \mathrm{E}+12$ & $7.51 \mathrm{E}+12$ \\
Aset Tetap & 310 & 0,001437 & 0,870447 & 0,264316 & 0,237465 \\
Aset Tak Berwujud & 310 & 0,000000 & 0,339486 & 0,017728 & 0,039911 \\
Pertumbuhan Penjualan & 310 & $-0,747320$ & 10,15333 & 0,097625 & 0,635498 \\
\hline
\end{tabular}

Sumber: Data Sekunder diolah Eviews 10 (2021)

Berdasarkan uji statistik deskriptif dapat disimpulkan bahwa pajak kini perusahaan di Indonesia tergolong rendah. Rendahnya pajak kini perusahaan dapat disebabkan oleh rendahnya profitabilitas perusahaan dan rendahnya pertumbuhan penjualan. Rendahnya pajak kini, profitabilitas, dan pertumbuhan penjualan dapat terlihat dari nilai rata-rata yang jauh dari angka 1.

Pengungkapan CSR dalam laporan keberlanjutan perusahaan di Indonesia masih tergolong rendah. Sehingga penelitian ini mendukung hasil riset yang telah dilakukan oleh NUS. Nilai minimal 0 pada variabel CSR terjadi karena terdapat perusahaan yang menerbitkan laporan keberlanjutan dua tahun sekali. Rata-rata perusahaan yang menerbitkan laporan keberlanjutan adalah perusahaan besar.

Nilai rata-rata leverage ada pada angka 0,5493 atau 54,93\%. Dapat disimpulkan, sumber pendanaan perusahaan di Indonesia berasal dari hutang. Hutang dipilih sebagai sumber pendanaan karena beban bunga pinjaman dapat mengurangi beban pajak penghasilan badan. Nilai rata-rata aset tetap yang rendah dapat terjadi karena rata-rata perusahaan yang menerbitkan laporan keberlanjutan adalah perusahaan yang bergerak disektor keuangan. 
Arus kas operasi memiliki nilai minimal -31.962.470.000.000, nilai maksimal 41.521.119.000.000 dan nilai rata-rata 3.233.540.529.209,956. Perbandingan standar deviasi dan nilai rata-rata adalah 232,3\% Berdasarkan perbandingan, nilai minimal dan nilai maksimal, nilai arus kas operasi memiliki kesenjangan yang sangat besar. Perusahaan Indonesia rata-rata tidak memiliki aset tak berwujud dan tidak memiliki aset tak berwujud yang besar.

\section{Regresi Panel \\ Uji Chow}

Tabel 2. Uji Chow

\begin{tabular}{|c|c|c|c|}
\hline Effect Test & Statistic & Prob. & Kesimpulan \\
\hline Cross-section F & 4,426594 & 0,0000 & \multirow{2}{*}{ Fixed effect Model } \\
\hline Cross-section Chi-Square & 260,421827 & 0,0000 & \\
\hline
\end{tabular}

Uji chow dilakukan untuk membandingkan model terbaik antara PLS dan FEM. Uji chow menunjukkan probabilitas cross-section chi-square 0,0000 atau di bawah 0,05. Dapat disimpulkan model terbaik untuk proksi ini adalah FEM.

\section{Uji Hausman}

Tabel 3. Uji Hausman

\begin{tabular}{llll}
\hline \hline Test Summary & Chi-Sq Statistic & Prob. & Kesimpulan \\
\hline Cross-section random & 7,097469 & 0,5262 & Random Effect Model \\
\hline
\end{tabular}

Sumber: Data Sekunder diolah Eviews 10 (2021)

Uji Hausman dilakukan untuk membandingkan model terbaik antara FEM dan REM. Uji hausman menunjukkan nilai probabilitas sebesar 0,5262 atau di atas 0,05. Dapat disimpulkan model terbaik untuk proksi ini adalah REM.

\section{Uji Lagrange Multiplier (LM)}

Tabel 4. Uji Lagrange Multiplier (LM)

\begin{tabular}{ccc}
\hline \hline Test Summary & Prob. & Kesimpulan \\
\hline Breusch-Pagan & 0,0000 & Random Effect Model \\
\hline Sumber: Data Sekunder diolah Eviews 10 (2021)
\end{tabular}

Uji LM dilakukan untuk membandingan model yang terbaik antara REM dan PLS. Uji LM menunjukkan nilai probabilitas sebesar 0,0000 atau di bawah 0,05. Dapat disimpulkan, model terbaik untuk proksi ini adalah REM.

\section{Uji Hipotesis}

Uji F

Tabel 5. Hasil Uji F

\begin{tabular}{cccc}
\hline \hline Variabel Dependen & Uji F & Sig. & Kesimpulan \\
\hline Current ETR & Prob $(F$-statistic $)$ & 0,000064 & Signifikan \\
\hline
\end{tabular}

\section{Sumber: Data Sekunder diolah Eviews 10 (2021)}

Hasil uji F menunjukkan nilai probabilitas sebesar 0,000064 atau lebih kecil daripada 0,05. Dengan demikian, dapat disimpulkan bahwa variabel-variabel independen secara simultan berpengaruh signifikan terhadap current ETR.

Uji T

Tabel 6. Uji T

\begin{tabular}{lrrl}
\hline \hline Variabel & Koefisien & Prob. & Kesimpulan \\
\hline Constant & $-0,827730$ & 0,0757 & \\
CSR & 0,153240 & 0,0200 & Signifikan \\
ROA & 0,486411 & 0,0464 & Signifikan \\
Ukuran Perusahaan & 0,037049 & 0,0167 & Signifikan \\
\hline
\end{tabular}




\begin{tabular}{lrrl}
\hline Leverage & $-0,259518$ & 0,0038 & Signifikan \\
Arus Kas Operasi & $4.45 \mathrm{E}-16$ & 0,7833 & Tidak Signifikan \\
Aset Tetap & $-0,007684$ & 0,9271 & Tidak Signifikan \\
Aset Tak Berwujud & $-0,941364$ & 0,0114 & Signifikan \\
Pertumbuhan Penjualan & $-0,009700$ & 0,5112 & Tidak Signifikan \\
\hline
\end{tabular}

Sumber: Data Sekunder diolah Eviews 10 (2021)

Hasil uji T menunjukkan CSR memiliki nilai probabilitas di bawah 0,05 dan nilai koefisien positif. Dapat disimpulkan CSR berpengaruh signifikan positif terhadap current ETR. Hal ini berarti semakin besar pengungkapan CSR maka semakin besar pajak kini perusahaan. Pajak kini yang besar menunjukkan perusahaan tidak terlibat dalam praktik penghindaran pajak yang agresif.

Hal ini dapat terjadi karena perusahaan di Indonesia memiliki kesadaran untuk bertanggung jawab kepada para pemangku kepentingan. Membayar pajak merupakan salah satu cara perusahaan bertanggung jawab kepada lingkungan sosial. Selain itu, perusahaan yang melaksanakan CSR cenderung menjadi perhatian publik. Sehingga, perusahaan yang melaksanakan CSR akan menghindari tindakan yang dapat merusak reputasi perusahaan. Hasil temuan ini mendukung hasil penelitian Park (2017), Kim \& Im (2017), Lanis \& Richardson (2018), López-González et al. (2019), dan Ortas \& Gallego-Álvarez (2020). CSR berpengaruh signifikan negatif terhadap praktik penghindaran pajak.

Profitabilitas berpegaruh signifikan positif terhadap current ETR. Semakin besar profitabilitas perusahaan maka semakin besar pajak kini perusahaan. Hal ini menunjukkan semakin besar profitabilitas perusahaan maka semakin besar pula kemampuan perusahaan membayar pajak. Hasil temuan ini berbanding terbalik dengan hasil penelitian Mohanadas et al. (2019).

Ukuran perusahaan berpengaruh signifikan positif terhadap current ETR. Semakin besar ukuran perusahaan maka semakin besar pajak kini perusahaan. Hal ini dapat terjadi karena perusahaan besar cenderung memiliki kemampuan lebih untuk membayar pajak. Selain itu, perusahaan besar cenderung ingin bertahan lama dalam masyarakat sehingga perusahaan besar akan menghindari penghindaran pajak yang agresif. Hasil penelitian ini didukung oleh hasil penelitian Kiesewetter \& Manthey (2017).

Leverage berpengaruh signifikan negatif terhadap current ETR. Semakin besar utang perusahaan maka semakin kecil pajak kini perusahaan. Hal ini dapat terjadi karena beban bunga pinjaman dapat mengurangi laba fiskal dalam perhitungan pajak penghasilan perusahaan. Dapat disimpulkan, perusahaan yang memiliki leverage yang tinggi cenderung melakukan penghindaran pajak. Hasil penelitian ini mendukung hasil penelitian Wiratmoko (2018) dan Mohanadas et al. (2019).

Arus kas operasi tidak berpengaruh signifikan terhadap current ETR. Hal ini dapat terjadi karena arus kas operasi yang besar tidak menjamin laba akhir yang besar pula. Arus kas operasi masih harus dikurangi arus kas keluar investasi dan arus kas keluar pendanaan untuk mendapatkan arus kas masuk bersih atau laba.

Aset tetap tidak berpengaruh signifikan terhadap current ETR. Ini menunjukkan perusahaan di Indonesia kurang mampu memanfaat beban depresiasi untuk mengurangi laba fiskal perusahaan. Beban depresiasi dari aset tetap dapat mengurangi pajak kini perusahaan.

Aset tak berwujud berpengaruh signifikan negatif terhadap current ETR. Walaupun berdasarkan uji statistik deskriptif rata-rata perusahaan Indonesia tidak memiliki aset tak berwujud yang besar, namun berdasarkan uji $\mathrm{T}$, aset tak berwujud berdampak signifikan terhadap penghindaran pajak. Hasil penelitian ini mendukung hasil penelitian Zeng (2019). Hal ini dapat terjadi karena aset tak berwujud memiliki nilai yang tidak pasti sehingga aset tak berwujud sulit untuk diukur nilai wajarnya. Hal ini banyak dimanfaatkan perusahaan untuk mentransfer kekayaan kepada perusahaan berafiliasi yang berada di negara dengan tarif pajak yang lebih rendah (Novira et al., 2020).

Pertumbuhan penjualan tidak berpengaruh signifikan terhadap penghindaran pajak. Hal ini dapat terjadi karena penjualan bukan merupakan angka final dalam perhitungan pajak penghasilan. Total penjualan harus dikurangi oleh beban-beban untuk mendapatkan laba sebelum pajak. Pertumbuhan penjualan belum tentu menunjukkan pertumbuhan laba apabila tidak diikuti 
oleh efisiensi biaya.

\section{Uji R (Goodness of Fit Model)}

Tabel 7. Uji R

\begin{tabular}{cc}
\hline \hline Variabel Dependen & Adjusted R-Squared \\
\hline Current ETR & 0,078701 \\
\hline \multicolumn{2}{c}{ Sumber: Data Sekunder diolah Eviews $10(2021)$}
\end{tabular}

Uji R dengan proksi dependen Current ETR memiliki nilai adjusted $R$-squared sebesar 0.078701. Hal ini berarti variabel-variabel independen yang diuji hanya dapat menjelaskan variabel Current ETR sebesar 7,87\% sedangkan 92,13\% lainnya dijelaskan variabel lain yang tidak terdapat dalam model penelitian ini. Masih banyak variabel yang dapat mempengaruhi praktik penghindaran pajak.

\section{KESIMPULAN}

Berdasarkan penelitian yang telah dilakukan dapat disimpulkan bahwa CSR berpengaruh signifikan negatif terhadap praktik penghindaran pajak. Semakin besar kinerja CSR perusahaan maka semakin besar pajak kini perusahaan atau menghindari praktik penghindaran pajak yang agresif. Hal ini dapat menjadi pertimbangan kepada para pembuat kebijakan untuk meningkatkan penerimaaan pajak negara dengan CSR. Melalui CSR, perusahaan juga dapat menjadi perpanjangan tangan pemerintah untuk membangun dan mensejahterakan masyarakat.

Karakteristik perusahaan seperti profitabilitas dan ukuran perusahaan berpengaruh signifikan negatif terhadap praktik penghindaran pajak. Perusahaan besar dengan profitabilitas yang tinggi cenderung memiliki kemampuan lebih untuk membayar pajak. Leverage dan aset tak berwujud berpengaruh signifikan positif terhadap praktik penghindaran pajak. Karakteristik perusahaan lainnya seperti aset tetap, arus kas operasi, dan pertumbuhan penjualan tidak berpengaruh signifikan terhadap praktik penghindaran pajak

\section{REFERENSI}

26000, I. (2017). ISO 26000. Iso 26000. https://doi.org/10.4324/9781351278843

Abdelfattah, T., \& Aboud, A. (2020). Tax avoidance, corporate governance, and corporate social responsibility: The case of the Egyptian capital market. Journal of International Accounting, Auditing and Taxation, 38, 100304. https://doi.org/10.1016/j.intaccaudtax.2020.100304

Anthony, R. N., Govindarajan, V., \& Bakir, S. (2011). Sistem Pengendalian Manajemen (jilid 2). //lib.ibs.ac.id/index.php?p=show_detail\&id=2344

Davis, A. K., Guenther, D. A., Krull, L. K., \& Williams, B. M. (2016). Do socially responsible firms pay more taxes? Accounting Review, 91(1), 47-68. https://doi.org/10.2308/accr-51224

Desai, M. A., \& Dharmapala, D. (2006). Corporate tax avoidance and high-powered incentives. Journal of Financial Economics, 79(1), 145-179. https://doi.org/10.1016/j.jfineco.2005.02.002

Fourati, Y. M., Affes, H., \& Trigui, I. (2019). Do Socially Responsible Firms Pay Their Right Part of Taxes? Evidence from the European Union. Journal of Applied Business and Economics, 21(1). https://doi.org/10.33423/jabe.v21i1.655

Friedman, M. (1970). A Theoretical Framework for Monetary Analysis. Journal of Political Economy, 78(6), 1385-1386. https://doi.org/10.1086/259720

Gazali, A., Karamoy, H., \& Gamaliel, H. (2020). Pengaruh Leverage, Kepemilikan Institusional dan Arus Kas Operasi Terhadap Penghindaran Pajak Pada Perusahaan Tambang yang Terdaftar di Bursa Efek Indonesia Periode 2014-2019. Jurnal Riset Akuntansi Dan Auditing “Goodwill," 11(2). https://ejournal.unsrat.ac.id/index.php/goodwill/article/view/30278 
Gulzar, M. A., Cherian, J., Sial, M. S., Badulescu, A., Thu, P. A., Badulescu, D., \& Khuong, N. V. (2018). Does corporate social responsibility influence corporate tax avoidance of Chinese listed companies? Sustainability (Switzerland), 10(12). https://doi.org/10.3390/su10124549

Hanlon, M., \& Heitzman, S. (2010). A review of tax research. Journal of Accounting and Economics, 50(2-3), 127-178. https://doi.org/10.1016/j.jacceco.2010.09.002

Hanlon, M., \& Slemrod, J. (2009). What does tax aggressiveness signal? Evidence from stock price reactions to news about tax shelter involvement. Journal of Public Economics, 93(12), 126-141. https://doi.org/10.1016/j.jpubeco.2008.09.004

Hoi, C. K., Wu, Q., \& Zhang, H. (2013). Is corporate social responsibility (CSR) associated with tax avoidance? Evidence from irresponsible CSR activities. Accounting Review, 88(6), 2025-2059. https://doi.org/10.2308/accr-50544

Initiative, G. R. (2016). Standar Pelaporan Keberlanjutan GRI 2016: 101 Landasan. Global Reporting Initiative, 30.

Jessica, \& Toly, A. R. (2014). Pengaruh Pengungkapan Program Corporate Social Responsibility. Tax \& Accounting Review, 4(1), 193-203.

Kemenkeu. (2019). MEMPERBAIKI JEJAK RASIO PAJAK. https://mediakeuangan.kemenkeu.go.id/Home/Detail/91/memperbaiki-jejak-rasio-pajak

Kiesewetter, D., \& Manthey, J. (2017). Tax avoidance, value creation and CSR - a European perspective. Corporate Governance (Bingley), 17(5), 803-821. https://doi.org/10.1108/CG08-2016-0166

Kim, J., \& Im, C. (2017). Study on corporate social responsibility (CSR): Focus on tax avoidance and financial ratio analysis. Sustainability (Switzerland), 9(10), 1-16. https://doi.org/10.3390/su9101710

Lanis, R., \& Richardson, G. (2012). Corporate social responsibility and tax aggressiveness: An empirical analysis. Journal of Accounting and Public Policy, 31(1), 86-108. https://doi.org/10.1016/j.jaccpubpol.2011.10.006

Lanis, R., \& Richardson, G. (2018). Outside directors, corporate social responsibility performance, and corporate tax aggressiveness: An empirical analysis. Journal of Accounting, Auditing and Finance, 33(2), 228-251. https://doi.org/10.1177/0148558X16654834

Lathifa, D. (2019). Hubungan Tax Avoidance, Tax Planning, Tax Evasion \& Anti Avoidance Rule. https://www.online-pajak.com/tentang-pajak/hubungan-tax-avoidance-tax-planningtax-evasion-anti-avoidance-rule

Liu, H., \& Lee, H. A. (2019). The effect of corporate social responsibility on earnings management and tax avoidance in Chinese listed companies. International Journal of Accounting and Information Management, 27(4), 632-652. https://doi.org/10.1108/JJAIM08-2018-0095

López-González, E., Martínez-Ferrero, J., \& García-Meca, E. (2019). Does corporate social responsibility affect tax avoidance: Evidence from family firms. Corporate Social Responsibility and Environmental Management, 26(4), 819-831. https://doi.org/10.1002/csr.1723

Mao, C. W., \& Wu, W. C. (2019). Moderated mediation effects of corporate social responsibility performance on tax avoidance: evidence from China. Asia-Pacific Journal of Accounting 
and Economics, 26(1-2), 90-107. https://doi.org/10.1080/16081625.2019.1546157

Mohanadas, N. D., Abdullah Salim, A. S., \& Pheng, L. K. (2019). CSR and tax aggressiveness of Malaysian listed companies: evidence from an emerging economy. Social Responsibility Journal, 16(5), 597-612. https://doi.org/10.1108/SRJ-01-2019-0021

Nazari, J. A., Hrazdil, K., \& Mahmoudian, F. (2017). Assessing social and environmental performance through narrative complexity in CSR reports. Journal of Contemporary Accounting and Economics, 13(2), 166-178. https://doi.org/10.1016/j.jcae.2017.05.002

Novira, A. R., Suzan, L., \& Asalam, A. G. (2020). Pengaruh Pajak, Intangible Assets, dan Mekanisme Bonus Terhadap Keputusan Transfer Pricing (Studi Kasus pada Perusahaan Sektor Pertambangan yang Terdaftar di Bursa Efek Indonesia Tahun 2015-2018). Journal of Applied Accounting and Taxation, 5(1), 17-23.

Ortas, E., \& Gallego-Álvarez, I. (2020). Bridging the gap between corporate social responsibility performance and tax aggressiveness: The moderating role of national culture. Accounting, Auditing and Accountability Journal, 33(4), 825-855. https://doi.org/10.1108/AAAJ-032017-2896

Park, S. (2017). Corporate social responsibility and tax avoidance: Evidence from Korean firms. Journal of Applied Business Research, 33(6), 1059-1068. https://doi.org/10.19030/jabr.v33i6.10045

Pratiwi, I. S., \& Siregar, S. V. (2019). The effect of corporate social responsibility on tax avoidance and earnings management: The moderating role of political connections. International Journal of Business, 24(3), 229-248.

Ramadhania, F. R. (2020). Determinan Tax Avoidance Pada Perusahaan Manufaktur di Indonesia Periode 2016-2018. Konferensi Riset Nasional Ekonomi, Manajemen, Dan Akuntansi I, $1149-1161$.

Renselaar, J. Van. (2016). The influence of corporate social responsibility on the level of corporate tax avoidance. 1-31. file:///C:/Users/youhe/Downloads/kdoc_o_00042_01.pdf

Richardson, G. A., \& Lanis, R. (2012). Corporate Social Responsibility and Tax Aggressiveness. SSRN Electronic Journal. https://doi.org/10.2139/ssrn.1904002

Richardson, G., \& Lanis, R. (2007). Determinants of the variability in corporate effective tax rates and tax reform: Evidence from Australia. Journal of Accounting and Public Policy, 26(6), 689-704. https://doi.org/10.1016/j.jaccpubpol.2007.10.003

RSAPE. (2020). Revenue Statistics in Asian and Pacific Economies.

Suastha, R. D. (2016). Riset Temukan Kualitas CSR Perusahaan Indonesia Rendah. https://www.cnnindonesia.com/nasional/20160721074144-20-146030/riset-temukankualitas-csr-perusahaan-indonesia-rendah

Susanti, E. (2018). Pengaruh Profitabilitas, Leverage, Sales Growth dan Ukuran Perusahaan terhadap Penghindaran Pajak (Studi Empiris pada Perusahaan Sektor Pertambangan dan Sektor Pertanian yang Listing di Bursa Efek Indonesia 2012-2017). Skripsi. Universitas Islam Indonesia Yogyakarta.

UU No. 36 Tahun 2008. (2008). Undang-Undang Republik Indonesia Nomor 36 Tahun 2008 Tentang Perubahan Keempat Atas Undang-Undang Nomor 7 Tahun 1983 Tentang Pajak Penghasilan. 
Wildan, M. (2020). OECD Sebut Rasio Pajak Indonesia Terendah di Asia-Pasifik. https://news.ddtc.co.id/oecd-sebut-rasio-pajak-indonesia-terendah-di-asia-pasifik-22572

Wiratmoko, S. (2018). The Effect of Corporate Governance, Corporate Social Responsibility, and Financial Performance on Tax Avoidance. The Indonesian Accounting Review, 8(2), 245. https://doi.org/10.14414/tiar.v8i2.1673

Zeng, T. (2019). Relationship between corporate social responsibility and tax avoidance: international evidence. Social Responsibility Journal, 15(2), 244-257. https://doi.org/10.1108/SRJ-03-2018-0056 